\title{
PENERAPAN PENDEKATAN SAVI UNTUK MENINGKATKAN HASIL BELAJAR FISIKA PADA SISWA KELAS XI SMA NEGERI 8 PALU
}

\author{
Sakka, Yusuf Kendek dan Kamaluddin \\ e-mail: sakha_rahma@yahoo.com \\ Program Studi Pendidikan Fisika FKIP Universitas Tadulako \\ Jl. Soekarno Hatta Km. 9 Kampus Bumi Tadulako Tondo Palu - Sulawesi Tengah
}

\begin{abstract}
Abstrak - Penelitian tindakan kelas ini bertujuan untuk meningkatkan hasil belajar fisika siswa kelas XI SMA Negeri 8 Palu. Masalah yang diteliti adalah rendahnya hasil belajar siswa pada mata pelajaran Fisika. Alternatif pemecahan masalah adalah menerapkan pendekatan pembelajaran SAVI. Subyek penelitian adalah siswa kelas XI SMA Negeri 8 Palu, dengan jumlah siswa 20 orang. Penelitian ini menggunakan Penelitian Tindakan Kelas yang dilaksanakan secara bersiklus dan mengacu pada desain penelitian dari model Kemmis \& Mc. Taggart, yang meliputi 4 tahap: (i) perencanaan (ii) pelaksanaan tindakan (iii) observasi (iv) refleksi. Jenis data yang diperoleh adalah data kualitatif dan data kuantitatif. Data kualitatif adalah data yang diperoleh dalam kegiatan belajar mengajar berupa observasi dan wawancara. Hasil observasi aktivitas siswa dan guru pada siklus I yaitu cukup dan baik, sedangkan siklus II berada pada kategori baik dan sangat baik. Sedangkan data kuantitatif adalah data hasil belajar yang diperoleh dengan tes. Hasil belajar siklus I diperoleh ketuntasan belajar klasikal yakni $65 \%$ dengan jumlah yang tuntas sebanyak 12 orang siswa dan yang belum tuntas 7 orang siswa. Pada siklus II ketuntasan belajar klasikal sebanyak 85 \% dengan rincian 17 orang siswa tuntas dan 3 orang siswa yang masih belum tuntas. Berdasarkan hasil tersebut dapat disimpulkan bahwa dengan penerapan pendekatan pembelajaran SAVI dapat meningkatkan hasil belajar siswa.
\end{abstract}

Kata Kunci: Pendekatan SAVI, Hasil Belajar Fisika

\section{PENDAHULUAN}

Proses pembelajaran pada hakikatnya adalah proses komunikasi, yaitu proses penyampaian pesan dari sumber yaitu guru dengan perantara media pendidikan tertentu ke penerima pesan yaitu siswa. Pesan yang akan dikomunikasikan adalah isi materi pelajaran. Oleh karena itu, proses pembelajaran yang tepat sangat diperlukan sebagai upaya untuk meningkatkan mutu pendidikan.

Proses belajar lebih dari sekedar mengingat materi pelajaran yang telah disampaikan. Siswa berusaha memecahkan masalah, menemukan sesuatu bagi dirinya sendiri. Tugas guru dalam proses pembelajaran adalah menuangkan informasi ke dalam benak siswa dan mengusahakan agar konsep-konsep penting tertanam kuat dalam benak siswa. Guru dapat membantu proses tersebut dengan cara mengajar yang membuat informasi menjadi bermakana dan relevan bagi siswa. Di samping itu, guru harus memberikan kesempatan kepada siswa agar mengembangkan strategi-strategi mereka sendiri dalam belajar.
Fisika merupakan pelajaran yang sudah sering dijumpai oleh siswa, mulai dari tingkat Sekolah Dasar sampai ke Perguruan Tinggi jika mengambil bidang fisika, namun tidak sedikit siswa yang masih berpendapat bahwa fisika adalah pelajaran yang menakutkan, pelajaran sulit dan kurang menarik, sehingga berpengaruh terhadap hasil belajar yang dicapai oleh siswa.

Siswa kelas XI semester genap SMA Negeri 8 Palu tahun pelajaran 20013/2014 mempunyai perhatian yang kurang terhadap pelajaran Fisika. Kenyataan tersebut diperkuat dengan fakta rendahnya nilai ulangan semester mata pelajaran Fisika. Dari hasil wawancara dan observasi peneliti dengan guru fisika kelas XI di SMA Negeri 8 Palu rendahnya nilai hasil belajar dapat dilihat dari nilai rata-rata hasil ujian semester Genap Kelas XI SMA Negeri 8 Palu Tahun Ajaran 2013/2014 adalah 64,21

Proses pembelajaran yang kurang menarik merupakan penyebab utama rendahnya kemampuan pemahaman siswa terhadap pelajaran. Siswa tidak mau bertanya kepada guru meskipun sebenarnya mereka belum mengerti tentang materi yang diajarkan guru 
sehingga menyebabkan hasil belajar siswa rendah.

Pendekatan pembelajaran yang digunakan oleh guru sangatlah berpengaruh terhadap hasil belajar siswa dalam pembelajaran, karena pendekatan yang digunakan oleh guru berkaitan erat dengan ketercapaian tujuan pembelajaran yaitu kompetensi. Oleh karena itu, pemilihan pendekatan yang salah akan mampu membuat hasil dari pembelajaran menurun, sehingga perlu adanya perhatian terhadap pendekatan yang digunakan guru dalam pembelajarannya.

Menurut Meier [1] pendekatan SAVI adalah pendekatan yang melibatkan indra pada tubuh yang mendukung pembelajaran, belajar dengan bergerak aktif secara fisik, dengan memanfaatkan indra sebanyak mungkin, dan membuat seluruh tubuh atau pikiran terlibat dalam proses belajar.

Dalam pendekatan SAVI, siswa dituntut ikut aktif dalam pembelajaran seperti melakukan percobaan, mengamati, mempresentasikan materi yang mereka peroleh, kemudian menyelesaikan permasalahan berdasarkan pengetahuan atau ilmu yang telah diperoleh siswa selama pembelajaran. Keterlibatan dalam embelajaran akan menarik minat siswa dalam belajar. Pasalnya siswa tidak hanya duduk diam dan mendengarkan guru berbicara di depan kelas. Selain itu, dengan bantuan media pembelajaran seperti animasi yang ditampilkan oleh guru, alat praktikum dan LKS (Lembar Kerja Siswa) sebagai perantara transfer materi, siswa dapat menggambarkan segala hal yang dipelajarinya sehingga mereka lebih memahami materi dan membantu melatih pola pikirnya dalam memahami konsep yang dipelajari.

Untuk meningkatkan hasil belajar fisika, perlu adanya kerjasama antara guru fisika dan peneliti yaitu melalui Penelitian Tindakan Kelas (PTK). Proses PTK ini memberikan kesempatan kepada peneliti dan guru fisika untuk mengidentifikasi masalah pembelajaran di sekolah sehingga dapat dikaji, ditingkatkan, dan dituntaskan. Dengan demikian proses pembelajaran fisika di sekolah, diharapkan dapat meningkatkan hasil belajar fisika.
Berdasarkan uraian yang telah dipaparkan di atas, peneliti tertarik untuk mengadakan penelitian mengenai "Penerapan Pendekatan SAVI (Somatis, Auditori, Visual, dan Intelektual) untuk Meningkatkan Hasil Belajar Fisika Pada Siswa Kelas XI SMA Negeri 8 Palu.

Berdasarkan uraian pada latar belakang di atas, maka dapat dirumuskan permasalahan sebagai berikut : Apakah dengan menerapkan Pendekatan SAVI dapat meningkatkan hasil belajar fisika pada siswa kelas XI SMA Negeri 8 Palu. Tujuan penelitian ini adalah untuk meningkatkan hasil belajar fisika pada siswa kelas XI SMA Negeri 8 Palu melalui penerapan pendekatan SAVI.

Pembelajaran tidak otomatis meningkat dengan menyuruh orang berdiri atau bergerak kesana kemari. Akan tetapi, menggabungkan gerakan fisik dengan aktifitas intelektual dan penggunaan semua indra dapat berpengaruh besar pada pembelajaran. Pendekatan seperti ini disebut dengan Pendekatan SAVI yaitu belajar yang melibatkan unsur: Somatis, Auditory, Visual, dan intelektual.

Menurut Nurmala [2]. Pembelajaran Fisika yang baik adalah bila tidak hanya melakukan kegiatan di kelas, atau hanya melibatkan proses dan produk yang selanjutnya hanya dapat menghasilkan penguasaan Fisika pada ranah kognitif dan psikomotor, tetapi lebih dari itu perlu ditambah dengan pemberian contohcontoh peristiwa atau manfaat Fisika di lingkungan dalam kehidupan sehari-hari. Dengan demikian, pembelajaran Fisika dapat meningkatkan penguasan siswa tentang Fisika pada ranah afektif. Kegiatan belajar mengajar merupakan salah satu faktor penting dalam pelaksanaan pembelajaran. Pelaksanaan pembelajaran selalu melibatkan dua komponen penting, yaitu siswa dan guru. Guru dalam pembelajaran berperan sebagai pelaksana kurikulum. Oleh karena itu, keberhasilan pembelajaran Fisika bukan hanya tergantung pada baiknya kurikulum Fisika, melainkan juga sangat tergantung pada guru bidang studi Fisika. Potensi guru berkaitan dengan mutu dan keprofesionalan dalam pembelajaran Fisika dapat dilihat dari kemampuannya dalam menerjemahkan kurikulum, menguasai bidang 
psikologis didaktik, dan melaksanakan penelitian pendidikan termasuk evaluasi.

Menurut Amann [3] Gegerakan fisik meningkatkan proses mental. Bagian otak manusia yang terlibat dalam gerakan tubuh terletak tepat disebelah bagian otak yang digunakan untuk berfikir dan memecahkan masalah. Oleh karena itu menghalangi gerakan tubuh berarti menghalangi pikiran untuk berfungsi secara maksimal. Sebaliknya, melibatkan tubuh dalam belajar cenderung membangkitkan kecerdasan terpadu manusia seluruhnya

Menurut Tornamen [4] Perkembangan anak dikelompokkan dalam empat kelompok yaitu:sensory, cognitive, socio-emotional, dan motor. Perhatian terbesarnya dikususkan pada aspek kematangan pikiran. (1) suara, gambar dan perasaan terdapat perbedaan dalam kemampuan merasakan, (2) anak-anak menggunakan strategi dan kemampuan berbahasa, (3) kemampuan socio-emotional menggunakan motivasi, mempertahankan ego, dan berorientasi lebih baik, (4) siswa dengan kemampuan somatis, fungsi groos motor dan sensor-motor baik dalam perkembangan gerak

\section{METODOLOGI PENELITIAN}

Jenis penelitian ini termasuk jenis penelitian tindakan kelas (PTK) dengan ciri utamanya adalah adanya tindakan yang berulang dan metode utamanya adalah refleksi yang bertujuan untuk memperbaiki pembelajaran.

Menurut Depdiknas [5] Desain penelitian ini mengacu pada model Kemmis dan MC.Taggart yaitu meliputi 4 tahap: (i) perencanaan (ii) pelaksanaan tindakan (iii) observasi (iv) refleksi. Apabila divisualisasikan, akan tergambar dalam bentuk diagram alur seperti terlihat pada Gambar 1.

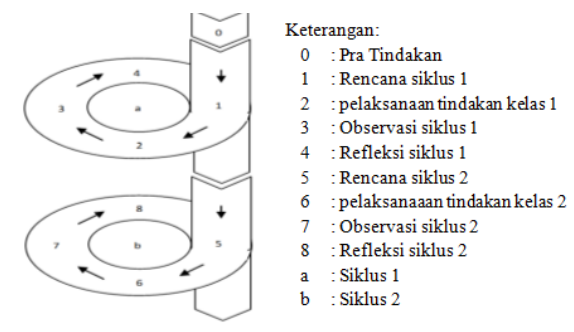

Penelitian ini dilaksanakan di SMA Negeri 8 Palu kelas XI dengan jumlah siswa atas 20 orang yang terdiri dari 6 laki-laki dan 14 orang perempuan yang mengikuti mata pelajaran fisika tahun ajaran 2014/2015.

Penelitian ini dilaksanakan pada tanggal 1 sampai tanggal 22 Oktober 2014. Penelitian ini dilakukan dalam dua siklus. Setiap siklus dilaksanakan sesuai dengan perubahan tingkah laku yang ingin dicapai. Sebelum dilaksanakan penelitian terlebih dahulu Berkolaborasi dengan guru fisika kelas XI MIA SMA Negeri 8 Palu untuk menggali permasalahan mata pelajaran fisika yang terjadi dikelas, serta tes awal pada siswa kelas XI SMA Negeri 8 Palu.

Peserta didik sebelum mendapatkan perlakuan dalam pembelajaran pada siklus I diadakan penilaian melalui tes berupa tes pratindakan, dan siswa yang sudah mendapatkan perlakuan dalam pembelajaran pada siklus I diadakan penilaian melalui tes berupa tes hasil belajar siklus I

Jenis data yang didapatkan dalam penelitian ini adalah data kuantitatif dan data kualitatif.

Sumber data dalam penelitian ini adalah guru (peneliti) dan siswa.

1. Data yang diperoleh dari guru (peneliti) berupa data hasil observasi saat proses pembelajaran berlangsung.

2. Data yang diperoleh dari siswa berupa hasil observasi dan hasil tes evaluasi belajar siswa.

Pada saat berlangsungnya kegiatan pembelajaran dilakukan pengamatan terhadap aktivitas siswa dan aktivitas guru. Untuk aktivitas siswa, yang dapat dinilai adalah aspek afektif, aspek kinerja kelompok sedangkan aktivitas guru, alat ukur yang digunakan yaitu lembar observasi yang telah disediakan. Hal yang dinilai adalah pembelajaran yang diterapkan terdiri dari tahap awal, inti dan penutup termasuk penyajian materi.

Wawancara dilakukan setelah evaluasi tindakan untuk mengetahui kesulitan-kesulitan yang dialami oleh siswa pada saat mengikuti proses pembelajaran.

Teknik analisa data yang digunakan dalam menganalisa data kuantitatif yang diperoleh 
dari hasil tes belajar dan menentukan persentase ketuntasan belajar

Data kualitatif yang diambil pada penilitian ini adalah penilaian aktivitas siswa dan aktivitas guru. Aspek yang diaamati terdiri dari tiga tahap yaitu tahap awal, tahap inti dan tahap penutup.

Indikator kualitatif pembelajaran dapat dilihat dari aktivitas siswa dan pengelolaan pembelajaran oleh guru, dan hasil analsisis terhadap penilaian afektif, psikomotor siswa. Penelitian ini dinyatakan berhasil jika kualitas hasil belajar untuk aspek yang dinilai tersebut telah berada dalam kategori baik atau sangat baik.

Indikator keberhasilan penelitian tindakan ini apabila melebihi nilai rata-rata ujian semester sebelum melaksanakan PTK $(64,21)$. (SMA Negeri 8 Palu).

\section{HASIL DAN PEMBAHASAN}

Kegiatan observasi aktivitas siswa dilakukan untuk melihat keaktifan siswa selama proses pembelajaran berlangsung. Aspek yang diaamati dalam observasi aktivitas siswa terdiri dari tiga tahap yaitu tahap awal, tahap inti dan tahap penutup. Dalam penilaian aktivitas siswa terdapat 9 aspek yang diobservasi. Setiap aktivitas diberikan skor 1 sampai dengan 4, dengan kategori sangat baik di skor 4, baik di skor 3, cukup di skor 2 dan kurang di skor 1

Presentase skor rata-rata yang diperoleh pada siklus pertama sebesar 70,83\%. Setelah diperoleh masukan dari hasil refleksi pada siklus I, aktivitas belajar siswa mengalami peningkatan menjadi $90,28 \%$ dengan peningkatan skor sebesar 19,45\%.

Kegiatan observasi aktivitas guru juga dilakukan untuk mengetahui aktivitas guru dalam mengelola pembelajaran. Pengamatan dilakukan oleh guru mata pelajaran fisika di SMA Negeri 8 Palu sebagai Observer. Aspek yang diamati dalam observasi aktivitas guru juga terdiri dari tiga tahap yaitu tahap awal, tahap inti dan tahap penutup. Dalam penilaian aktivitas guru terdapat pula 9 aspek yang diobservasi. Setiap aktivitas diberikan skor 1 sampai dengan 4, dengan kategori sangat baik di skor 4, baik di skor 3, cukup di skor 2 dan kurang di skor 1 . Presentase skor rata-rata yang diperoleh pada siklus pertama sebesar $75 \%$. Setelah diperoleh masukan dari hasil refleksi pada siklus I, aktivitas belajar siswa mengalami peningkatan menjadi $90,28 \%$ dengan peningkatan skor sebesar 15,28\%. Untuk lebih jelasnya peningkatan presentase aktivitas siswa dan guru dapat dilihat pada Tabel 1 dan Gambar 2

Tabel 1 Presentase Aktivitas Siswa dan Guru

\begin{tabular}{|c|c|c|c|}
\hline \multirow{2}{*}{ No } & \multirow{2}{*}{ Aktivitas } & \multicolumn{3}{|c|}{ Presentase Skor } \\
\cline { 3 - 4 } & & Siklus I & Siklus II \\
\hline 1 & Siswa & $70,83 \%$ & $90,28 \%$ \\
\hline 2 & Guru & $75 \%$ & $90,28 \%$ \\
\hline
\end{tabular}

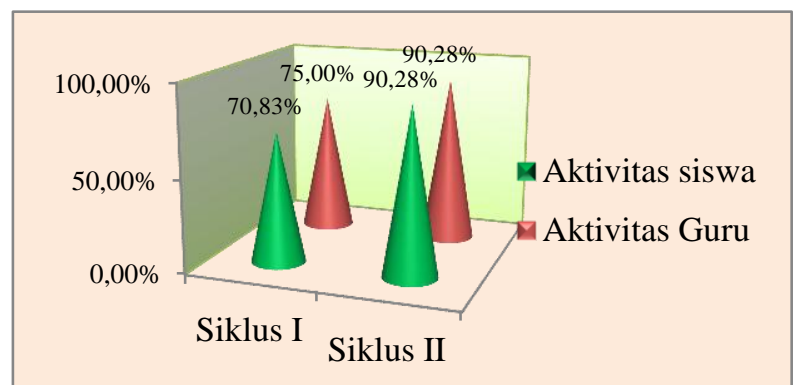

Gambar 2 Grafik Peningkatan Aktivitas Siswa dan Guru

Berdasarkan data hasil belajar dan observasi guru dan siswa selama kegiatan pembelajaran di tiap siklus, diambil kesimpulan bahwa aktivitas siswa selama mengikuti proses pembelajaran siklus I dan II menurut pengamat sudah baik. Hal ini dapat dilihat dari grafik peningkatannya pada Gambar 2.

Penilaian afektif siswa terdapat 5 aspek yang diamati dan untuk penilaian psikomotor siswa terdapat 4 aspek yang diamati. Setiap aspek pada penilaian afektif siswa akan di berikan skor 1, 2, 3, 4 dan 5 sesuai dengan rubrik penilaian afektif. Penilaian afektif siswa dapat dilihat pada tabel 2 dan gambar 3

\begin{tabular}{|c|c|c|c|c|}
\hline \multirow{2}{*}{ No } & \multirow{2}{*}{\multicolumn{2}{|c|}{ Siklus }} & \multicolumn{2}{|c|}{ Presentase } \\
\hline & & & Skor & Rata-rata \\
\hline \multirow{2}{*}{1} & \multirow{2}{*}{ Siklus I } & Pertemuan I & $77,2 \%$ & \multirow{2}{*}{$80,1 \%$} \\
\hline & & Pertemuan II & $83 \%$ & \\
\hline
\end{tabular}




\begin{tabular}{|c|c|c|c|c|}
\hline \multirow{2}{*}{2} & \multirow{2}{*}{$\begin{array}{c}\text { Siklus } \\
\text { II }\end{array}$} & Pertemuan I & $88 \%$ & \multirow{2}{*}{$90,8 \%$} \\
\cline { 3 - 4 } & & Pertemuan II & $93,6 \%$ & \\
\hline
\end{tabular}

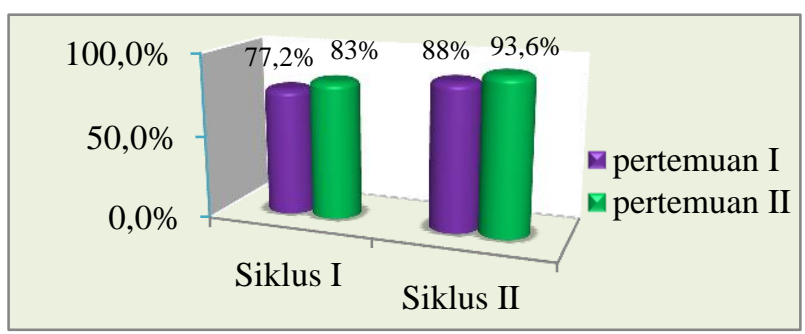

Gambar 3 Grafik Peningkatan Afektif Siswa

Penilaian sikap dilakukan pada saat tindakan sedang berlangsung. Pada awal pembelajaran, keaktifan siswa masih belum nampak. Hal ini disebabkan karena siswa belum terbiasa dengan pendekatan pembelajaran SAVI. Namun pada pertemuan berikutnya, siswa sudah mulai aktif dalam proses pembelajaran. Hal ini disebabkan karena siswa sudah mengetahui langkah-langkah yang mereka kerjakan. Selain itu, siswa sudah berantusias untuk mengemukakan pertanyaan, pendapat dan menjawab pertanyaan yang diajukan, serta memiliki inisiatif untuk terlibat langsung dalam kegiatan yang dilakukan selama proses pembelajaran. Hal ini dapat dilihat dari grafik peningkatannya pada Gambar 3

Tabel 3 Presentase Penilaian Psikomotor Siswa

\begin{tabular}{|l|c|c|c|c|}
\hline \multirow{2}{*}{ No } & \multicolumn{2}{|c|}{ Siklus } & \multicolumn{2}{c|}{ Presentase } \\
\cline { 3 - 4 } & \multicolumn{2}{|c|}{ Skor } & $\begin{array}{c}\text { Rata- } \\
\text { rata }\end{array}$ \\
\hline \multirow{2}{*}{1} & \multirow{2}{*}{$\begin{array}{c}\text { Siklus } \\
\text { I }\end{array}$} & Pertemuan I & $68,5 \%$ & \multirow{2}{*}{$76,7 \%$} \\
\cline { 3 - 4 } & Pertemuan II & $85,0 \%$ & \\
\hline \multirow{2}{*}{2} & \multirow{2}{*}{$\begin{array}{c}\text { Siklus } \\
\text { II }\end{array}$} & Pertemuan I & $88,0 \%$ & \multirow{2}{*}{$89,2 \%$} \\
\cline { 3 - 4 } & & Pertemuan II & $90,5 \%$ & \\
\hline
\end{tabular}

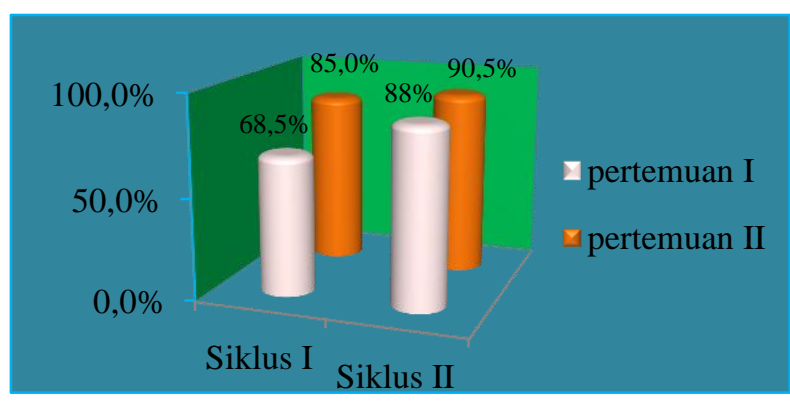

Gambar 4 Grafik Peningkatan Psikomotor Siswa
Aktivitas psikomotor siswa setiap pertemuannya pada siklus I masih kurang dan untuk pertemuan pada siklus II sudah baik. Kinerja dari masing-masing siswa pada kelompoknya ini meningkat pada setiap pertemuannya. Hal ini menunjukkan bahwa kemampuan serta keterampilan siswa pada saat kegiatan yang dilakukan selama proses pembelajaran sudah mulai meningkat pula. Siswa yang awalnya kurang melibatkan dirinya terhadap kegiatan kelompok, sudah menunjukkan peningkatan setiap pertemuan yang berarti rasa keingintahuan siswa terhadap kegiatan yang dilakukan sudah lebih tinggi. Hal ini dapat dilihat dari grafik peningkatannya pada gambar 4.

Hasil Belajar siswa dapat dilihat dari hasil evaluasi setelah pelaksanaan pembelajaran berlangsung. Secara umum hasil belajar siswa yang diperoleh mengalami peningkatan. Hasil belajar siswa dapat dilihat pada Tabel 4 dan Gambar 5.

Tabel 4 Data hasil Belajar Siswa
\begin{tabular}{|c|c|c|}
\hline No & Siklus & Nilai Rata-rata \\
\hline 1 & $\begin{array}{l}\text { nilai rata-rata pada } \\
\text { semester tahun } \\
\text { ajaran 2013/2014 }\end{array}$ & 64,21 \\
\hline 2 & Pratindakan & 64,3 \\
\hline 3 & Siklus I & 64,7 \\
\hline 4 & Siklus II & 77,0 \\
\hline
\end{tabular}

Berikut ini merupakan grafik nilai ratarata hasil belajar siswa pada semester tahun ajaran 2013/2014, tes awal, siklus I dan siklus II.

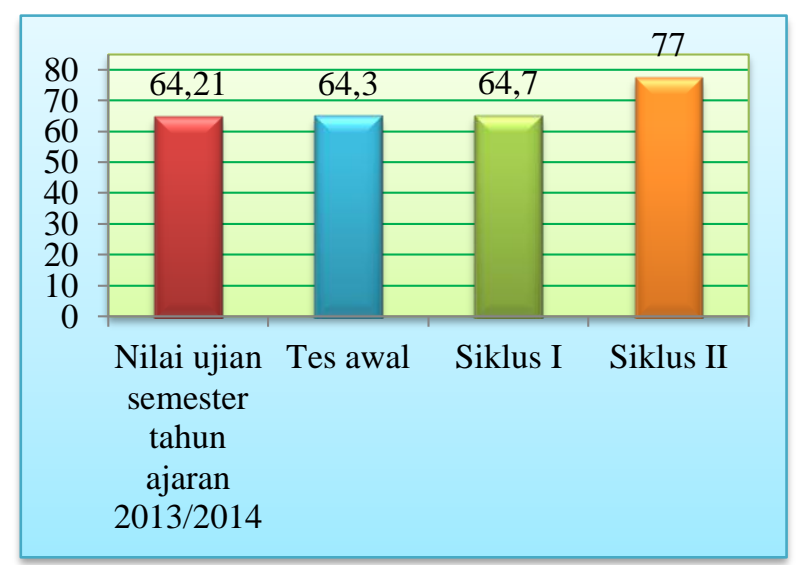

Gambar 5 Grafik Nilai Rata-rata Hasil Belajar Siswa pada semester tahun ajaran 2013/2014, tes awal,Siklus I dan Siklus II 
Hasil nilai rata-rata yang diperoleh siswa pada nilai semester genap tahun ajaran 2013/2014, tes pratindakan, tes akhir tindakan siklus I dan tes akhir tindakan siklus II mengalami peningkatan di setiap tahapannya seperti yang terlihat pada gambar 5 .

Dari grafik terlihat bahwa hasil yang diperoleh pada siklus II lebih baik dari siklus I. Peningkatan ini terjadi karena kekurangankekurangan yang terdapat pada siklus I dapat diminimalisir. Peningkatan hasil yang signifikan dapat dilihat pada ketuntasan belajar klasikal yang mencapai $85,0 \%$ atau terdapat 17 siswa yang tuntas dari 20 siswa yang mengikuti ujian.

Berdasarkan hasil refleksi siklus I terdapat beberapa kelemahan-kelemahan yang dijadikan tolak ukur guru guna perbaikan pada siklus selanjutnya.

Pada siklus II, peneliti lebih mendisiplinkan siswa serta menanyakan kesiapan siswa untuk menerima materi sebelum pembelajaran dimulai, peneliti lebih menekankan batas waktu saat kegiatan kelompok sehingga siswa lebih disiplin dalam memanfaatkan waktu, selalu memberikan kesempatan kepada siswa untuk bertanya, menciptakan suasana keakraban dengan siswa serta selalu memotivasi siswa untuk berani memberi tanggapan sehingga mereta tidak ragu-ragu dan malu untuk bertanya. Peneliti juga lebih mengarahkan siswa agar saling bekerjasama serta membimbing siswa untuk melakukan kerja sama dalam kelompok dan mendiskusikan penyelesaian soal bersama teman kelompok sehingga tugas mereka terasa lebih mudah. Dari perbaikan-perbaikan inilah sehingga siswa merasa lebih senang dengan pendekatan pembelajaran yang diterapkan saat belajar.

Penerapan pendekatan pembelajaran SAVI ini dapat memberikan pengalaman baru serta menciptakan suasana yang menyenangkan bagi siswa, sehingga dapat meningkatkan hasil belajar fisika siswa. Peningkatan tersebut dapat dilihat pada hasil pelaksanaan tindakan siklus II. Pada hasil pelaksanaan siklus II, diperoleh ketuntasan klasikal mencapai $85,0 \%$ dan daya serap klasikal $77 \%$ dari perolehan tersebut menunjukkan hasil lebih baik dari siklus I.

\section{KESIMPULAN}

Berdasarkan hasil penelitian dan pembahasan dapat disimpulkan bahwa penerapan pendekatan SAVI dapat meningkatkan hasil belajar fisika siswa kelas XI MIA SMA Negeri 8 Palu. Hal ini dapat dilihat pada hasil belajar pada siklus I dan siklus II setelah menerapkan pendekatan SAVI lebih tinggi dibandingkan hasil belajar semester tahun ajaran 2013/2014 sebelum menggunakan pendekatan SAVI. Indikator kualitatif pembelajaran juga sudah memenuhi indikator kinerja yang ditetapkan dimana aktivitas guru dan aktivitas siswa sudah berada dalam kategori baik dan sangat baik. Kemudian hasil wawancara siswa menunjukkan bahwa siswa senang dengan pendekatan pembelajaran yang diterapkan.

\section{DAFTAR PUSTAKA}

[1] Meier, Dave. (2002). The accelerated learning handbook: panduan kreatif dan efektif merancang program pendidikan dan pelatihan. Bandung : MMU(Mizan media utama).

[2] Nurmala. (2006). Perbedaan Hasil Belajar Fisika Siswa yang Menerima Pelajaran dengan Menggunakan dan Tanpa Menggunakan Alat Peraga pada Pokok Bahasan Kalor di Kelas II Semester 1 MTs Negeri 1 Medan Tahun Ajaran 2005/2006, Skripsi FMIPA, Unimed, Medan.

[3] Amann,T.L. (2008). Creating Space for Somatic Ways of Knowing Whithin Tranformative Learning Theory. Journal of Physics Teacher Education. Vol. 2 (4). 26 halaman.

[4] Tornamen, M.R.K. (2009). Auditory-Visual Matching and Language-Based Learning Disoders: two Studiesmof Specific Language Impairment and Developmental Dyslexia. International Journal of Education 26, (2), 9-10.

[5] Departemen Pendidikan Nasional. (2004). Penilaian. Jakarta: Departemen Pendidikan Nasional (Revisi 1 April 2004), Jakarta: Depdiknas. 